\title{
Corrigendum: Helicobacter pylori cagA+ Is Associated with Milder Duodenal Histological Changes in Chilean Celiac Patients
}

\begin{abstract}
Yalda Lucero ${ }^{1,2,3 *}$, Amaya Oyarzún ${ }^{4}$, Miguel O'Ryan ${ }^{2,5}$, Rodrigo Quera $^{6}$, Nelly Espinosa ${ }^{7}$, Romina Valenzuela ${ }^{1}$, Daniela Simian ${ }^{6}$, Elisa Alcalde ${ }^{8}$, Claudio Arce ${ }^{8}$, Mauricio J. Farfán ${ }^{1,8}$, Alejandra F. Vergara ${ }^{8}$, Iván Gajardo ${ }^{1}$, Jocelyn Mendez ${ }^{8}$, Jorge Carrasco ${ }^{8}$, Germán Errázuriz ${ }^{6}$, Mónica González ${ }^{9}$, Juan C. Ossa ${ }^{1}$, Eduardo Maiza ${ }^{10}$, Francisco Perez-Bravo ${ }^{11}$, Magdalena Castro ${ }^{6}$ and Magdalena Araya ${ }^{4}$

${ }^{1}$ Department of Pediatrics and Pediatric Surgery, Faculty of Medicine, University of Chile, Santiago, Chile, ${ }^{2}$ Microbiology and Micology Program, ICBM, Faculty of Medicine, University of Chile, Santiago, Chile, ${ }^{3}$ Pediatric Gastroenterology Unit, Department of Pediatrics, Clínica Alemana-Universidad del Desarrollo, Santiago, Chile, ${ }^{4}$ Laboratory of Immunegenetics, Institute of Nutrition and Food Technology, University of Chile, Santiago, Chile, ${ }^{5}$ Millenium Institute of Immunology and Immunotherapy, Faculty of Medicine, University of Chile, Santiago, Chile, ${ }^{6}$ Department of Gastroenterology, Clínica Las Condes, Santiago, Chile, ${ }^{7}$ Hospital Militar, Santiago, Chile, ${ }^{8}$ Hospital Dr. Luis Calvo Mackenna, Santiago, Chile, ${ }^{9}$ Hospital Dr. Roberto del Río, Santiago, Chile, ${ }^{10}$ Clínica Las Lilas, Santiago, Chile, ${ }^{11}$ Nutrition Program, Faculty of Medicine, University of Chile, Santiago, Chile
\end{abstract}

Keywords: celiac disease, potential celiac disease, Helicobacter pylori, cagA gene, duodenal atrophy

\section{OPEN ACCESS}

Edited and reviewed by: D. Scott Merrell, Uniformed Services University, United States

*Correspondence: Yalda Lucero ylucero@gmail.com

Received: 06 September 2017 Accepted: 19 September 2017 Published: 29 September 2017

Citation:

Lucero Y, Oyarzún A, O'Ryan M, Quera R, Espinosa N, Valenzuela $R$ Simian D, Alcalde E, Arce C, Farfán MJ, Vergara AF, Gajardo I, Mendez J, Carrasco J, Errázuriz G, González M, Ossa JC, Maiza E, Perez-Bravo F, Castro M and Araya M (2017) Corrigendum: Helicobacter pylori cagA+ Is Associated with Milder

Duodenal Histological Changes in Chilean Celiac Patients.

Front. Cell. Infect. Microbiol. 7:427. doi: 10.3389/fcimb.2017.00427

\section{A corrigendum on}

Helicobacter pylori cagA + Is Associated with Milder Duodenal Histological Changes in Chilean Celiac Patients

by Lucero, Y., Oyarzún, A., O’Ryan, M., Quera, R., Espinosa, N., Valenzuela, R., et al. (2017). Front. Cell. Infect. Microbiol. 7:376. doi: 10.3389/fcimb.2017.00376

In the published article, there was an error in affiliation (2). Instead of "Microbiology and Micology Program, Faculty of Medicine, University of Chile, Santiago, Chile," it should be "Microbiology and Micology Program, ICBM, Faculty of Medicine, University of Chile, Santiago, Chile." The authors apologize for this error and state that this does not change the scientific conclusions of the article in any way.

Additionally, there was an error regarding the affiliations for Yalda Lucero. Affiliation 8 has been removed and the following affiliation has been added instead: Pediatric Gastroenterology Unit, Department of Pediatrics, Clínica Alemana-Universidad del Desarrollo, Santiago, Chile.

Conflict of Interest Statement: The authors declare that the research was conducted in the absence of any commercial or financial relationships that could be construed as a potential conflict of interest.

Copyright () 2017 Lucero, Oyarzún, O’Ryan, Quera, Espinosa, Valenzuela, Simian, Alcalde, Arce, Farfán, Vergara, Gajardo, Mendez, Carrasco, Errázuriz, González, Ossa, Maiza, Perez-Bravo, Castro and Araya. This is an open-access article distributed under the terms of the Creative Commons Attribution License (CC BY). The use, distribution or reproduction in other forums is permitted, provided the original author(s) or licensor are credited and that the original publication in this journal is cited, in accordance with accepted academic practice. No use, distribution or reproduction is permitted which does not comply with these terms. 